\title{
The Effect Of Transformational Leadership, Job Satisfaction, And Organizational Commitments Toward Organizational Citizenship Behavior Of Indonesian Senior High School Teachers
}

\author{
M. Shofiyuddin, Universitas Pekalongan, Indonesia \\ Arif Budiharjo, Universitas Pekalongan, Indonesia \\ Casrameko, Institut Agama Islam Negeri Pekalongan, Indonesia \\ Nur Khotimah, SMPN 1 Batang, Jawa Tengah, Indonesia \\ Ahmad Syarifudin, MTs Al Fithrah Semarang,Indonesia \\ Hudiyati, UIN Walisongo Semarang,Indonesia \\ Ahmad Musyafak, UIN Walisongo Semarang,Indonesia \\ Nasitotul Janah, Universitas Muhammadiyah Magelang, Indonesia \\ Ratna Wijayanti, Universitas Sains Al-Qur'an Jawa Tengah di Wonosobo, Indonesia \\ Agus Purwantoi, Universitas Pelita Harapan, Indonesia \\ Coresponding Author :agozpor@gmail.com
}

\begin{abstract}
The purpose of this study was to determine and examine the effect of transformational leadership, organizational commitment and job satisfaction on organizational citizenship behavior in high schools in Banten Province. The sample in this study was taken from 220 teacher respondents. Sampling in this study using the Simple Random Sampling technique. The analysis technique used is multiple regression analysis. The results of the analysis and testing show that transformational leadership has a positive and significant effect on teachers' organizational citizenship behavior, job satisfaction has a positive and significant effect on teacher organizational citizenship behavior, organizational commitment has a positive and significant effect on teacher organizational citizenship behavior. This study has proven that transformational leadership, Organizational commitment and job satisfaction influence organizational citizenship behavior in SMA in Banten Province.
\end{abstract}

Keywords: Senior high school, Transformational leadership, job satisfaction, organizational commitment, organizational citizenship behavior

Received: 07.12.2020 $\quad$ Accepted: 12.01.2021 $\quad$ Published: 02.02.2021

\section{INTRODUCTION}

According to Achmadi (2020); Basri (2020) \& Bahdin (2020) Human resource is a very important thing in companies and organizations because the success and effectiveness of an organization or company is very dependent on the quality of human resources owned by the organization. Human resources are often the determinants of the existence of the company they shelter in, so companies should no longer view human resources as a burden, but as an organizational asset. According to Cahyono (2020); Pramono (2020) \& Kadiyono (2020) state that human resources have a very vital role in every company, so that the achievement of a company goal is very dependent on its own human resources. Without human resources in a company, the company's activities will not run.

According to Nelvitia (2020); Sartika (2020) \& Vizano (2020) The concept of Organizational Citizenship Behavior in the field of organizational behavior has emerged since two decades ago and until now Organizational Citizenship Behavior continues to develop.Like other companies, in service providers, Organizational Citizenship Behavior is very much needed. Companies whose operations are highly dependent on human resources, from the process of selling products to serving consumers, need an Organizational Citizenship Behavior to carry out all of their operational activities. This is because it is not enough for human resources in the company to only carry out their respective duties without having extra role behavior, especially when the office is crowded and a number of tasks cannot be done properly by the teacher.

According to Nico (2020) \& Yunita (2020); Purwanto (2020) \& Ardi (2020) Organizational Citizenship Behavior is a deep contribution that exceeds the demands of roles in the workplace and earns awards from companies based on the tasks that have been carried out. Organizational Citizenship Behavior is the key to the success of an organization, for example, when the reciprocity felt by the teacher 
is not as expected, it will have an impact on reducing the teacher's intention to carry out extra-role behavior (OCB). Teachers who often work overtime can work more efficiently in terms of time and energy if they can raise organizational citizenship behavior.

According to Vizano (2020); Sena (2020) \& Yunita (2020) Social exchange theory is a theory that is often used to explain why a teacher is willing to show Organizational Citizenship Behavior (OCB). This theory is based on two assumptions, reciprocity and equity. When a teacher experiences a relatively positive influence or perception in an organization, he or she will return the favor in the most practical and effective way, and Organizational Citizenship Behavior (OCB) is one of the best ways to demonstrate that this proves the ethical environment of an organization has influence. the teacher.

According to Purwanto (2020) \& Ardi (2020), Organizational Citizenship Behavior (OCB) or extra-role behavior is behavior in organizations that does not directly receive rewards from the formal reward system. According to research observations, there is a problem, namely the level of Organizational Citizenship Behavior (OCB) in senior high school can be said to be quite low, this was revealed during a short interview and direct observation with a number of senior high school teachers. The results of interviews from several teachers showed that schools really need teachers who have more roles outside their work so that they can work more effectively in achieving organizational goals, but this has not been able to be realized because there are still employees who take actions that are not in accordance with the rules there is like excusing yourself at work, chatting with other employees, all of which has nothing to do with work. This can also be seen from the attitude of employees who only do their own duties and responsibilities without having the desire to help other colleagues, who have more workloads and tend to work individually and this can be triggered by differences in each individual which includes experience. , knowledge, training and awareness of the work attitude they have.

In ideal conditions, employees should have an OCB role by showing voluntary behavior to be willing to carry out tasks or other work that are outside their own responsibilities and obligations in order to achieve organizational goals. Therefore, to increase OCB, it is necessary to have factors that influence it, including transformational leadership, job satisfaction and organizational commitment. This is because organizational citizenship behavior (OCB) plays an important role in the reciprocal exchange process in organizations, according to; Purwanto (2020) \& Ardi (2020) state that research on Organizational Citizenship Behavior has been carried out and several factors have been shown to influence Organizational Citizenship Behavior. In line with Nico (2020) \& Yunita (2020), the factors that influence the emergence of Organizational Citizenship Behavior are individual dispositions and motives, group cohesiveness, employee attitudes which include job satisfaction and organizational commitment, transformational leadership style and organizational justice.

According to Kartika (2020); Fahmi (2020); Jannah (2020) defines transformational leadership as a form of leadership where people engage with others and create relationships that increase motivation and morality in leaders and followers. Surbakti (2013) states that the interaction between a leader who has a transformational leadership style and his subordinates is characterized by the size or size of the influence the leader exerts on his subordinates to change. Leaders who apply this type of transformational leadership will tend to spur their followers to produce work beyond what is expected, namely by changing the vision, becoming an example, providing support, and stimulating the desire to change for the better. Followers have trust, admiration, loyalty, and respect for their leader, so they will easily do more work than expected. Leaders transform and motivate followers using charisma and intellectuality.

According to Yunita (2020); Purwanto (2020) \& Ardi (2020) state that leaders have direct power that is able to have an extraordinary impact on followers. Leadership is a process where individuals are able to influence and move group members in achieving common goals, so that the leadership style of managers will greatly determine how teachers behave. Transformational leadership as described by Asbari (2020) is a leadership style that emphasizes the process by which people engage with others and create relationships that increase motivation in both the leader and the followers. Leaders who use a transformational leadership style tend to pay more attention to their followers. In addition to the type of leadership, several studies also show that job satisfaction has a positive and significant influence on Organizational Citizenship Behavior, so it is considered very important for organizations to pay attention to the job satisfaction of their members. Job satisfaction is a person's emotional response to work situations and conditions in the form of dissatisfaction. or a sense of satisfaction

According to Ardi (2020), job satisfaction is the difference between what is obtained and what should be obtained. The less difference is obtained, it can be said that the individual is satisfied with his job. According to Nugroho (2020); Nico (2020) \& Yunita (2020); state a number of dimensions of job satisfaction are satisfaction with colleagues, satisfaction with management, compensation has a major contribution to job satisfaction felt by teachers. Organizational Citizenship Behavior improvement 
depends on the job satisfaction felt by the teacher, if the teacher has good job satisfaction it will have an effect on their performance in the organization. Swaminathan (2013) argues that employee OCB is influenced by increased job satisfaction, which will have a positive effect on the achievement of company goals. Job satisfaction is something that cannot be measured only from physical observation. Job satisfaction can only be concluded if workers directly express their satisfaction with the work they are doing, someone who is satisfied with their work will tend to have a positive attitude towards the organization where they work.

Another factor that triggers Organizational Citizenship Behavior is organizational commitment. According to Fahmi (2020), organizational commitment is a term used to describe the readiness of a teacher to accept organizational goals and face work. Sena (2020), said the factors that encourage organizational citizenship behavior of employees are influenced by several motives, namely commitment to organizations where there is a desire to participate well in the organization and be proud to be part of the organization. The standards applied by the organization, organizational principles, ethics and organizational values to remain within the scope of the organization.Commitment is said to be one of the factors that can contribute to the efficiency of the organization itself. According to Achmadi (2020); Basri (2020) states that organizational commitment refers to organizational principles, organizational standards, accepting and realizing organizational goals, organizational ethics and organizational values to remain in the organization in all situations and the readiness of teachers to work hard. According to Achmadi (2020); Basri (2020); Bahdin (2020); Bernarto (2020); Cahyono (2020); Pramono (2020) says that organizational commitment is a condition in which a teacher defends an organization and has the goal of maintaining its membership in the organization.

According to Nelvitia (2020); Sartika (2020) said that teachers who have a high commitment to the organization can better identify the goals and objectives of the organization and remain in the organization. According to Achmadi (2020); Basri (2020); Bahdin (2020) defines that organizational commitment is the attitude of teachers or organizational strength in binding teachers to remain in the organization. Adiapsari (2012) stated that the willingness to work hard to achieve organizational goals and having a strong desire to work and remain in the institution where he works shows that the teacher has organizational commitment. According to Kadiyono (2020); Kartika (2020) states that organizational commitment can be seen from a number of factors, namely the desire to remain in the organization, the willingness to achieve organizational goals, trust and acceptance of the organization. According to Achmadi (2020) \& Ardi (2020), organizational commitment is an attitude of teachers that reflects their feelings towards the organization they take shelter in.

Based on the results of preliminary observations (observations) on senior high school teachers, it was found that there was a lack of initiative when providing services to students. The teacher's lack of responsiveness in responding to student requests. Leaders have not been able to coordinate thoroughly about the change plans that will be carried out due to the lack of understanding of the teacher, so that the change process will be slightly hampered. Based on this background, this study will examine transformational leadership, job satisfaction. , organizational commitment, and organizational citizenship behavior (OCB) in senior high school

The purpose of this study 1) to examine the effect of transformational leadership on organizational citizenship behavior (OCB) in senior high schools, 2) to examine the effect of job satisfaction on organizational citizenship behavior (OCB) in senior high school, and 3) to examine the effect of commitment. Organizational Citizenship Behavior (OCB) in senior high school. The benefits of this study are expected to be used as reference material in matters related to Organizational Citizenship Behavior (OCB) learning, and can be used as a contribution to efforts to improve Organizational Citizenship Behavior ( OCB) in each company by knowing the factors that can influence the emergence of extra role behavior. A number of studies have been conducted to determine the effect of transformational leadership on organizational citizenship behavior.

The results of Asbari's (2020) study show that transformational leadership has a positive effect on organizational citizenship behavior that is owned by teachers. the application of high transformational leadership, the level of Organizational Citizenship Behavior will also increase (Rahmi, 2013).Based on a number of studies above, the following hypothesis can be formulated:

H1: Transformational leadership has a positive and significant effect on Teacher Organizational Citizenship Behavior.

Some studies have been conducted to determine the effect of teacher job satisfaction on Organizational Citizenship Behavior (OCB). Results of research conducted by Bahdin (2020); Bernarto (2020) states that job satisfaction is positively and significantly correlated with organizational citizenship behavior. According to Pramono (2020); Kadiyono (2020); Kartika (2020); Fahmi (2020); Jannah (2020); Nelvitia (2020); Sartika (2020) ); Vizano (2020); Sena (2020) that job satisfaction has a positive effect on 
organizational citizenship behavior. Research conducted by Sartika (2020); Vizano (2020); Sena (2020) et al. (2011) found that satisfaction work has a significant positive impact on organizational citizenship behavior. According to Vizano (2020); Sena (2020) proves that there is a significant positive effect of job satisfaction on Organizational Citizenship Behavior (OCB) in middle school teachers. According to Vizano (2020); Sena (2020) stated that job satisfaction can not only affect the Organizational Citizenship Behavior, it can also be influenced by the Organizational Citizenship Behavior itself. According to Sena (2020), get the same results, that job satisfaction has a positive and significant effect on Organizational Citizenship Behavior. The higher the job satisfaction, the higher the level of Organizational Citizenship Behavior in the teacher. Based on this, the following hypothesis can be formulated: teachers.

H2: Job satisfaction has a significant positive effect on the Organizational Citizenship Behavior of

Research conducted to examine the effect of organizational commitment on Organizational Citizenship Behavior (OCB) shows that organizational commitment has a significant effect on Organizational Citizenship Behavior (OCB). According to Bahdin (2020); Bernarto (2020); Sena (2020) tested the effect of organizational commitment on Organizational Citizenship Behavior (OCB) and found that organizational commitment has a significant positive effect on Organizational Citizenship Behavior (OCB)

According to Fahmi (2020); Jannah (2020); Nelvitia (2020); Sartika (2020); Vizano (2020); Sena (2020) obtained results that affirmative commitment and normative commitment have a positive effect on Organizational Citizenship Behavior, while continuance commitment has no effect on Organizational Citizenship Behavior, the result is that the overall form of commitment affects Organizational Citizenship Behavior significantly. Other research conducted by Sartika (2020); Vizano (2020); Sena (2020) show that organizational commitment has a significant positive effect on Organizational Citizenship Behavior. The same thing is also shown from the results of research by Vizano (2020); Sena (2020) who get the results that organizational commitment has a positive effect on organizational citizenship behavior. Based on this, the following hypothesis can be formulated:

H3: Organizational commitment has a positive and significant effect on Teacher Organizational Citizenship Behavior.

\section{METHOD}

The research method used is quantitative research methods, namely research using positivism philosophy with the type of causality because this study aims to determine the effect of independent variables consisting of transformational leadership, job satisfaction and commitment.organizational citizenship behavior to the dependent variable(OCB). This quantitative analysis is similar conducted by Achmadi (2020); Basri (2020); Bahdin (2020); Bernarto (2020); Cahyono (2020); Pramono (2020); Kadiyono (2020); Kartika (2020); Fahmi (2020); Jannah (2020); Nelvitia (2020); Sartika (2020); Vizano (2020); Sena (2020); Nugroho (2020); Nugroho (2020); Nico (2020) \& Yunita (2020); Purwanto (2020) \& Ardi (2020)

The dependent variable used in this study is organizational citizenship behavior (OCB) or extrarole behavior, which is individual behavior that is not listed in formal job requirements but is voluntarily carried out by teachers and is able to increase organizational effectiveness (Organ, 1995). The indicator used to measure the level of organizational citizenship behavior of teachers which refers to (Allison, 2001) is 1) Altruism, the willingness to help colleagues in completing their work in unusual situations, 2) Courtesy, behavior helps prevent problems related to work, 3) Sportsmanship, the productivity of a worker in tolerating less than ideal situations at work, 4) Conscientiousness, carrying out tasks and responsibilities more than expected, 5) Civic Virtue, workers' support for administrative functions in the organization.

The independent variables used are transformational leadership (X1), job satisfaction (X2) and organizational commitment (X3). Transformational leadership (X1) is a type of leadership that emphasizes interactions that result in increased motivation and morality in leaders and followers and changes in emotions, values, ethics, standards and goals of each leader and follower (Northouse, 2013: 176 ). The indicators used to measure transformational leadership referring to Tschannen-Moran (2003) are, 1) Idealized influence, belief a strong self in delivering the goals of a transformational leader.2) Inspirational motivation, the efforts of transformational leaders to inspire their followers to reach unimaginable possibilities. 3) Intellectual stimulation, the efforts of transformational leaders to invite teachers to see new perspectives. 4) Individualized consideration, the behavior of a transformational leader, in which he thinks, reflects on and identifies the needs his teachers need.

Job satisfaction (X2) is a person's emotional attitude regarding their job performance. Attitudes like this 
can be positive or negative (Hasibuan, 2007) and (Taskina, 2009). The indicators used to measure teacher job satisfaction are, 1) Work It Self, teachers tend to prefer jobs that provide opportunities to use freedom, skills and abilities as well as feedback. 2) Supervisor, supervision has an important role in an organization because it relates to employees directly and influences their work. 3) Workers, for most employees, work is a way to meet the needs of social interaction. 4) Promotion, when promoted, employees generally face an increase in demands for responsibility, ability and expertise. 5) Pay, the teacher wants a wage system that is perceived in accordance with his expectations, fair and not in doubt. Organizational commitment (X3) is a psychological attachment felt by teachers to the organization they belong to. (Robbins, 2008: 101). The indicators used to measure the organizational commitment of teachers which refer to (Meyer and Allen, in Cotzee, 2005) are, 1) Affective commitment, a person's emotional involvement to their organization in the form of feelings of love for the organization. 2) Continuance commitment, a person's perception based on the risks and costs of leaving the organization at this time. 3) Normative commitment, a moral dimension based on responsibility and a feeling of obligation to the employing organization.

The data in this study use primary and secondary data. Primary data in this study were obtained directly from the teacher, in the form of a questionnaire that had been filled in by the teachers. Secondary data in this study is in the form of data in the amount of 2016. The population of this study were all 220 teachers. In this study, the sampling technique used was saturated sampling technique, because the sample under study was the entire population. Given the number of respondents as a sample of 220 people, so it is feasible to take the whole of them as respondents.

Data collection methods used in this research are 1) observation methods, namely data collection by direct observation of the object under study, 2) interviews, namely data collection through direct interviews with respondents and using a list of questions to obtain information related to research 3) questionnaires, namely a list of questions asked of respondents to be filled in according to perception respondents regarding, job satisfaction, organizational commitment and organizational citizenship behavior (OCB). The questionnaire in this study uses a Likert scale in its measurement. The analysis technique in this study uses multiple regression, this analysis technique is used to produce direct conclusions about the effect of each independent variable consisting of transformational leadership, job satisfaction and organizational commitment to the dependent variable, namely organizational citizenship behavior (OCB), both partially. as well as together. The regression model used is.

$\mathrm{Y}=\alpha+\beta 1 \mathrm{X} 1+\beta 2 \mathrm{X} 2+\beta 3 \mathrm{X} 3+\varepsilon(1)$

Information :

$\mathrm{Y}=$ Organizational Citizenship Behavior (OCB) X1 = Transformational Leadership

$\mathrm{X} 2=\mathrm{Job}$ Satisfaction

$\mathrm{X} 3=$ Organizational Commitment

$\alpha=$ Constant

$\beta 1=$ Transformational leadership regression coefficient

$\beta 2=$ Job satisfaction regression coefficient

$\beta 3=$ Organizational commitment regression coefficient

$\varepsilon=$ error

\section{RESULT AND DISCUSION}

This study was conducted to determine the effect of transformational leadership, job satisfaction, and organizational commitment on organizational citizenship behavior. The data collection technique is done through a questionnaire with a questionnaire method.

Table 1.Results of Multiple Linear Regression Analysis

Unstandardized

\begin{tabular}{|c|c|c|c|c|c|}
\hline Model & Coefficients & Coefficients & $t$ & Sig. & \\
\hline B & Std.Error & & Beta & & \\
\hline (Constant) & 2.449 & 1.484 & & 1.732 & 059 \\
\hline Transformational & 401 & 163 & 318 & 3.022 & .005 \\
\hline \multicolumn{6}{|l|}{ Leadership } \\
\hline Job Satisfaction & 233 & .110 & 227 & 2.370 & .082 \\
\hline $\begin{array}{l}\text { Organizational } \\
\text { Commitment }\end{array}$ & .570 & .156 & 396 & 3.076 & .005 \\
\hline $\mathrm{R}$ & & & & & 0,874 \\
\hline R Square & & & & & 0,781 \\
\hline
\end{tabular}




\begin{tabular}{||l|l|l|l|l|}
\hline F Statistix & & & & 25,437 \\
\hline Significant & & & & 0,000 \\
\hline
\end{tabular}

Based on the results of multiple linear regression analysis as presented in Table 1. the structural equation is as follows:

$\mathrm{Y}=2.449+0.401 \mathrm{X} 1+0.233 \mathrm{X} 2+0.570 \mathrm{X} 3+\mathrm{e}$

The total coefficient of determination of 0.781 means that $78.1 \%$ of the variation in Organizational Citizenship Behavior is influenced by variations in Transformational Leadership, Job Satisfaction and Organizational Commitment, while the remaining $21.9 \%$ is explained by other factors not included in the model.

Table 2. Normality Test

Unstandardized Residual

\begin{tabular}{|l|l|}
\hline $\mathrm{N}$ & 43 \\
\hline Kolmogorov-SmirnovZ & 0,345 \\
\hline Asymp.Sig.(2-tailed) & 1,000 \\
\hline
\end{tabular}

Based on Table 2. it can be seen that the Kolmogorov Sminarnov value (K-

S) of 0.345 , while the value of Asymp. Sig. (2-tailed) of 1,000. These results indicate that the regression equation model is normally distributed because of the Asymp value. Sig. (2-tailed) 0.345 is greater than an alpha value of 0.05 .

Table 3. Multicollinearity Test Results

\begin{tabular}{|l|l|l|}
\hline Variable & Tolerance & VIF \\
\hline Transformational Leadership $\left(\mathrm{X}_{1}\right)$ & 0,509 & 1,659 \\
\hline Job Satisfaction $\left(\mathrm{X}_{2}\right)$ & 0,637 & 1,458 \\
\hline Organizasional Commitment $\left(\mathrm{X}_{3}\right)$ & 0,694 & 1,514 \\
\hline
\end{tabular}

Based on Table 3, it can be seen that the tolerance and VIF values of all variables indicate that the tolerance value for each variable is greater than $10 \%$ and the VIF value is less than 10 , which means that the regression equation model is free from multicollinearity.

Table 4. Heteroskedastisitas Test Result

\begin{tabular}{|c|c|c|c|c|c|c|}
\hline Model & & $\begin{array}{l}\text { Unstandardized } \\
\text { Coefficients }\end{array}$ & & & $\begin{array}{l}\text { Standardized } \\
\text { Coefficients }\end{array}$ & \\
\hline & B & Std. Error & Beta & & $t$ & Sig. \\
\hline (Constant) & -2.984 & 1.484 & & & -2.063 & .051 \\
\hline $\begin{array}{l}\text { Transformational } \\
\text { Leadership } \\
\text { Job Satisfaction }\end{array}$ & $\begin{array}{l}055 \\
1.125 \\
\end{array}$ & $\begin{array}{l}.046 \\
.674 \\
\end{array}$ & & .155 & $\begin{array}{l}875 \\
1.728 \\
\end{array}$ & $\begin{array}{r}.399 \\
.058 \\
\end{array}$ \\
\hline \begin{tabular}{|l|} 
Organizational \\
Commitmnet
\end{tabular} & .075 & .092 & & .121 & 671 & .524 \\
\hline
\end{tabular}

In Table 4. it can be seen that the Sig. from the variables of Transformational Leadership, Job Satisfaction, and Organizational Commitment, respectively $0.399,0.058$ and 0.524 . This value is greater than 0.05 , which means that there is no influence between the independent variables on absolute residuals. Thus, the model made does not contain heteroscedasticity symptoms.

Table 5. Annova Test

\begin{tabular}{|l|l|l|l|l|l|}
\hline Model & Sum of Squares & Df & Mean Square & F & Sig. \\
\hline $1 \quad$ Regression & 190.514 & 3 & 63.541 & 25.437 & $.000^{\mathrm{a}}$ \\
\hline Residual & 74.810 & 30 & 2.439 & & \\
\hline Total & 265.324 & 33 & & & \\
\hline
\end{tabular}

The ANOVA test results table above shows that the dk between groups (comparison) $=3$, $\mathrm{dk}$ in the group (denominator) $=33$, at alpha $=0.05$, the $\mathrm{F}$ table value is $0.05(3.33)=2.89$. Medium $\mathrm{F}$ count $=$ 
25.473. Value of Fcount $>$ Ftable, 25.473 $>2.89$, with a sig. $0.000<0.05$. Then $\mathrm{H} 0$ is rejected at the 0.05 level (H1 is accepted). In conclusion, the tested group has a significant difference (significant).

Based on the results of hypothesis testing, the effect of Transformational Leadership on Organizational Citizenship Behavior obtained a Sig.t value of 0.005 with a beta coefficient value of 0.410 . The Sig.t value of $0.005<0.05$ indicates that

$\mathrm{HO}$ is rejected and $\mathrm{H} 1$ is accepted. The results of this study prove that there is a positive and significant influence between transformational leadership on extra-role behavior (OCB) in teachers. organizational citizenship behavior (OCB).

According to Achmadi (2020); Basri (2020) and Bahdin (2020) transformational leadership has a positive and significant effect on organizational citizenship behavior., The results of this study are in line with research conducted by Bernarto (2020); Cahyono (2020); Pramono (2020); Kadiyono (2020) and Kartika (2020) that transformational leadership has a positive and significant effect on organizational citizenship behavior, according to Nugroho (2020); Nico (2020) \& Yunita (2020); Purwanto (2020) \& Ardi (2020) states that transactional leadership has a positive and significant effect on organizational citizenship behavior. The results of this study are in line with research conducted by Nugroho (2020); Nugroho (2020); Nico (2020) \& Yunita (2020); Purwanto (2020) \& Ardi (2020) stated that transformational leadership has a positive and significant effect on organizational citizenship behavior. According to Sena (2020); Nugroho (2020); Nugroho (2020); Nico (2020) \& Yunita (2020); Purwanto (2020) \& Ardi (2020) states that transfromational and transactional leadership has a positive and significant effect on organizational citizenship behavior. The results of this study are in line with research conducted by Cahyono (2020); Pramono (2020); Kadiyono (2020); Kartika (2020); Fahmi (2020); Jannah (2020) states that transformational and transactional leadership has a positive and significant effect on organizational citizenship behavior.

These results indicate that conveying the organization's vision and mission clearly, inspiring subordinates, stimulating subordinates' creativity and being able to train subordinates will improve teacher OCB behavior. Increased OCB behavior is characterized by increased behavior to help colleagues voluntarily, obeying Senior high school regulations, not providing issues that can bring down other teachers, helping to alleviate problems faced by fellow teachers and supporting organizational functions in a professional manner. OCB behavior of teachers can be improved by increasing the intensity of the application of transformational leadership. The results of this study show that theoretically, the highest indicator lies in the inspiration motivation indicator, while practically the highest indicator lies in idealized influence. This shows that although theoretically the inspiration from the leadership in carrying out work, practically the delivery of the vision and mission of the leadership can increase morale, so that the better the delivery of the vision and mission from the leadership, the higher the optimism of the teacher in completing the work.

Based on the analysis of the effect of Job Satisfaction on Organizational Citizenship Behavior, the Sig.t value is 0.028 with a beta coefficient value of 0.233 . The Sig.t value of $0.028<0.05$ indicates that $\mathrm{H} 0$ is rejected and $\mathrm{H} 1$ is accepted. The results of this study prove that there is a positive and significant influence between job satisfaction and extra-role behavior (OCB) in teachers. According to Cahyono (2020); Pramono (2020); Kadiyono (2020); Kartika (2020); Fahmi (2020); Jannah (2020); Nelvitia (2020); Sartika (2020); Vizano (2020); Sena (2020); Nugroho (2020) job satisfaction has a positive and significant effect on organizational citizenship behavior, the results of this study are in line with Sartika (2020); Vizano (2020); Sena (2020); Nugroho (2020); Nugroho (2020); Nico (2020) \& Yunita (2020) which state that job satisfaction has a positive and significant effect on organizational citizenship behavior

Based on the results of the analysis of the effect of Organizational Commitment on Organizational Citizenship Behavior, the Sig.t value is 0.005 with a beta coefficient value of 0.507 . The Sig.t value of 0.005 $<0.05$ indicates that $\mathrm{HO}$ is rejected and $\mathrm{H} 1$ is accepted. The results of this study prove that there is a positive and significant influence between organizational commitment to extra-role behavior (OCB) in teachers. According to Bahdin (2020); Bernarto (2020); Cahyono (2020); Pramono (2020); Kadiyono (2020); Kartika (2020); Fahmi (2020); Jannah (2020); Nelvitia (2020); Sartika (2020); Vizano (2020); Sena (2020) organizational commitment has a positive and significant effect on organizational citizenship behavior, the results of this study are in line with Nelvitia (2020); Sartika (2020); Vizano (2020); Sena (2020); Nugroho (2020); Nugroho (2020) which states that organizational commitment has a positive and significant effect on organizational citizenship behavior. The results of this study indicate that teachers who get job satisfaction will bring out their willingness to do work outside the job description. The existence of a match between wages according to workload, working responsibly, doing a good job will be promoted, treated well by leaders and enjoying working with friends in the work environment will increase teacher OCB behavior. Increasing the OCB score of teachers can be done by increasing their 
job satisfaction. The results of this study indicate that teachers who feel proud of senior high school, have concerns if they leave senior high school and believe that someone should be loyal to their organization. Increased OCB behavior is characterized by increased behavior characterized by increased behavior to help colleagues voluntarily, obeying Senior high school regulations, not providing issues that can bring down other teachers, helping to alleviate problems faced by fellow teachers and supporting functions organization in a professional manner. Teachers 'OCB behavior can be improved by increasing the intensity of implementing subordinates' organizational commitment. The results of this study indicate that practically and theoretically the highest indicator lies in affective commitment. So that the higher the sense of pride a teacher has towards their Senior high school, the higher the organizational commitment of the teacher

\section{CONCLUSION}

The results of the analysis show that transformational leadership has a positive and significant effect on organizational citizenship behavior, job satisfaction has a positive and significant effect on organizational citizenship behavior, organizational commitment has a positive and significant effect on organizational citizenship behavior, and this study also succeeds in proving that transformational leadership, job satisfaction, and organizational commitment affects organizational citizenship behavior in senior high schools in Banten Province.Based on the results of research analysis, discussion and conclusions, there are several suggestions that can be used as consideration in determining future policies, especially those related to transformational leadership, job satisfaction, organizational commitment and organizational citizenship behavior, including: practically, to be able to to increase OCB, it must pay attention to inspirational motivation indicators which are indicators of transformational leadership related to inspiring subordinates to always be optimistic in achieve company goals that can be improved by the leadership by communicating expectations tall than his subordinates, has a high vision for his subordinates, is optimistic and enthusiastic and gives encouragement and the meaning of what needs to be done. Promotion opportunities which are an indicator of job satisfaction related to doing a good job, I will be promoted this can be done by way of members opportunities for employees to be able to develop better creativity and innovation to achieve them optimal organizational goals and continuance commitment, which are indicators of commitment Organizational concerns have concerns if leaving the company can be improved through employee attendance and reduce employee dissatisfaction with the organization that will be able to improve teacher OCB. on the organizational commitment variable. If these indicators can be improved, of course it will further increase organizational citizenship behavior. Theoretically, to be able to increase organizational citizenship behavior, one must pay attention to indicators of inspirational motivation on transformational leadership variables, indicators of promotion opportunities on job satisfaction variables and indicators

\section{REFERENCE}

Ardi, A., Djati, S. P., Bernarto, I., Sudibjo, N., Yulianeu, A., Nanda, H. A., \& Nanda, K. A. (2020a). The Relationship Between Digital Transformational Leadership Styles and Knowledge-Based Empowering Interaction for Increasing Organisational Innovativeness. International Journal of Innovation, Creativity and Change, 11(3), 259-277.

Ardi, A., Djati, S. P., Bernarto, I., Sudibjo, N., Yulianeu, A., Nanda, H. A., \& Nanda, K. A. (2020b). The Secret to Enhancing Innovativeness in the Digital Industry. International Journal of Innovation, Creativity and Change, 12(12), 225-243.

Mulyadi, Sudibjo, N., \& Bernarto, I. (2017). The Effect of Perceived Organizational Support, Work Engagement, and Job Satisfaction on Teacher's Performance at Xyz Middle and High School. International Journal of Economic Research, 14(13), 7-19.

Khoiri, A., Sobarna, . A., Sarwani, ., Siagian, . A. O., S, . R. Y., Kusworo, ., Surasni, ., Rahmanita, . F., Gunartin, ., Hidayati, . S., Purwanto, . A., Faroh, . W. N., Masadi, . M., Sunarsi, . D. \& Teriyan, . A. (2020) An Overview: Inquiry Based Science Learning Models in Empowering Creative Thinking Skills High School Student. Systematic Reviews in Pharmacy, 11 (11), 1466-1476. doi:10.31838/srp.2020.11.207

Nugroho, . B. S., Widdah, . M. E., Suryana, . A. T., Ibrahim, . T., Humaira, . M. A., Nasrudin, . M., Mubarok, . M. S., Abadi, . M. T., Adisti, . A. R., Gadzalia, . S. S., Muqtada, . M. R., Purwanto, . A., Fahlevi, . M. \& Sudargini, . Y. (2020) Effect of Leadership Style Toward Indonesian Education Performance in Education 4.0 Era: A Schematic Literature Review. Systematic Reviews in Pharmacy, 11 (10), 371378. doi:10.31838/srp.2020.10.60 
Quddus, A., Nugroho, . B. S., Hakim, . L., Ritaudin, . M. S., Nurhasanah, . E., Suarsa, . A., Karyanto, . U. B., Tanjung, . R., Hendar, ., Pratama, . V. Y., Awali, . H., Mufid, . A., Purwanto, . A., Fahlevi, . M. \& Sudargini, . Y. (2020) Effect of Ecological, Servant dan Digital Leadership Style Influence University Performance? Evidence from Indonesian Universities. Systematic Reviews in Pharmacy, 11 (10), 408-417. doi:10.31838/srp.2020.10.64

Nugroho, B. S., Widdah, . M. E., Hakim, . L., Nashirudin, . M., Nurlaeli, . A., Purnomo, . J. H., Aziz, . M., Adinugraha, . H. H., Sartika, . M., Fikri, . M. K., Mufid, . A., Purwanto, . A. \& Fahlevi, . M. (2020) Effect of Organizational Citizenship Behavior, Work Satisfaction and Organizational Commitment toward Indonesian School Performance. Systematic Reviews in Pharmacy, 11 (9), 962-971. doi:10.31838/srp.2020.9.140

, Sartika, . N. S., Subroto, . D. E., Mauladaniyati, . R., Rosdianwinata, . E., Rifai, . R., Sujana, . A., Abidin, . Z., Priadi, . M. D., Setiawati, . E., Yanti, . D. \& Purwanto, . A. (2020) Effect of Pedagogic, Professional Competency, and Work Motivation Toward Indonesian Primary School Teachers Performance. Systematic Reviews in Pharmacy, 11 (9), 617-626. doi:10.31838/srp.2020.9.91

Achmadi, H., Antonio, . F., Pramono, . R., Bernarto, . I. \& Purwanto, . A. (2020) Identification of The Positive and Negative Emotions that Appeared among High School Students When Selecting University at Jakarta and Surrounding Area. Systematic Reviews in Pharmacy, 11 (9), 759-766. doi:10.31838/srp.2020.9.107

Roojil Fadillaha, Miftahus Sururb, Elfriantoc, Ahmad Khoirur Roziqind, Achmad Suhailie, Rina Asih Handayanif, Abdul Mufidg, Agus Purwantoh, Muhajiri, Khaerul Fahmij (2020) THE INFLUENCE OF LEADERSHIP STYLE ON INNOVATION CAPABILITIES OF ISLAMIC SCHOOL TEACHERS IN ORGANIZATIONAL LEARNING PERSPECTIVE DURING COVID-19 PANDEMIC. Systematic Reviews in Pharmacy, 11 (7), 589-599. doi:10.31838/srp.2020.7.83

Basri, ., Wibowo, . T. S., Abdillah, . A., Kharis, . A., Jaenudin, ., Purwanto, . A., Mufid, . A., Maharani, . S., Badi ati, . A. Q., Fahlevi, . M. \& Sumartiningsih, . S. (2020) Democratic, Authocratic, Bureaucratic and Charismatic Leadership Style: Which Influence School Teachers Performance in Education 4.0 Era?. Systematic Reviews in Pharmacy, 11 (9), 277-286. doi:10.31838/srp.2020.9.45

Supriadi, O., Musthan, . Z., Saodah, ., Nurjehan, . R., Haryanti, . Y. D., Marwal, . M. R., Purwanto, . A., Mufid, . A., Yulianto, . R. A., Farhan, . M., Fitri, . A. A., Fahlevi, . M. \& Sumartiningsih, . S. (2020) Did Transformational, Transactional Leadership Style and Organizational Learning Influence Innovation Capabilities of School Teachers during Covid-19 Pandemic?. Systematic Reviews in Pharmacy, 11 (9), 299-311. doi:10.31838/srp.2020.9.47

Kadiyono, A. L., Sulistiobudi, . R. A., Haris, . I., Wahab, . M. K. A., Ramdani, . I., Purwanto, . A., Mufid, . A., Muqtada, . M. R., Gufron, . M., Nuryansah, . M., Ficayuma, . L. A., Fahlevi, . M. \& Sumartiningsih, . S. (2020) Develop Leadership Style Model for Indonesian Teachers Performance in Education 4.0 Era. Systematic Reviews in Pharmacy, 11 (9), 363-373.doi:10.31838/srp.2020.9.52 